B. Zhumanova*, PhD, assoc. professor ${ }^{l}$

N. Alashbayeva, master of science, senior lecturer ${ }^{l}$

A. Imashev, $P h D$, senior lecturer ${ }^{l}$

K. Baigabulova, $P h D$, assoc. professor ${ }^{2}$

Kazakh University of Economics Finance and International Trade ${ }^{l}$

Nur-Sultan, Kazakhstan

Eurasian national University L.N. Gumilyova ${ }^{2}$

Nur-Sultan, Kazakhstan

* - main author (author for correspondence)

e-mailnukanai09@bk.ru

\title{
IMPLEMENTATION OF DIGITALIZATION IN THE MANAGEMENT OF TRANSPORT AND LOGISTICS SYSTEM OF KAZAKHSTAN
}

The article presents the conditions for a culture of digitalization's formation of the transport and logistics sector of the economy of Kazakhstan and considers the main stages of the implementation of the state program "Digital Kazakhstan», based on the basic principles of the development of economic sectors, through the introduction of new technologies and improvement of existing business processes. The authors define the goals and objectives of the development of the transport and logistics structure.

The consistency of the functioning of the project of an intelligent transport system is shown. Based on the results of the study of the transport industry in the framework of the modern development of the Republic of Kazakhstan's economy, the article's authors identified the main problematic aspects and constraints to further development associated with high costs of logistics services and low labor productivity. Based on the results of the study, the need for digital modernization of transport and logistics services in the sectors of the economy of Kazakhstan is justified.

Keyword: transport, transport industry, state program, digital Kazakhstan, food belt, economy, system, sector, development, function.

Кілт сөздер: көлік, көлік саласы, мемлекеттік бавдарлама, иифрлық Қазақ̧стан, азықтүлік белдеуі, экономика, жүйе, сектор, даму, функиия.

Ключевые слова: транспорт, транспортная отрасль, государственная программа, иичрровой Казахстан, продовольственный пояс, экономика, система, сектор, развитие, функиия.

JEL classification: $\mathbf{R} 41$

Introduction. Currently, the importance of the transport industry in the economy of each state is increasing, since the level of transport development directly affects the competitiveness of the economy and the security of the country. Transport is the most important sector of the domestic economy of Kazakhstan, which occupies a significant share in the GDP structure. Significant territory of the Republic and low population density, high rate of economic development of Kazakhstan, achieved in recent years, form the growing demand for transportation. Accordingly, the movement of population and cargo flows within the framework of inter-economic relations, economic development and interaction of the regions of Kazakhstan every year becomes more and more popular service. In addition to the economic function, transport performs a social function, provides contacts 
of the population within the framework of kinship, friendly communication, participates in the organization of recreation, education, cultural development, as well as in solving various social problems.

In the message of the head of state to the people of Kazakhstan "Strategy" Kazakhstan2050": a new political course of the established state" [1] the task is to double the transit traffic through Kazakhstan by 2020 and 10 times - by 2050. "It is important to focus on going beyond the country to create production transport and logistics facilities" - said the President of the Republic of Kazakhstan.

The draft state program for the development of transport infrastructure until 2020 was developed with the support of the world Bank and has been approved previously by all interested state and local Executive bodies and associations. In fact, this is the first large-scale plan in the history of the country for the development of Kazakhstan's transport infrastructure and its integration into the world transport system [2].

The purpose of this study is to study modern approaches in the management of the transport and logistics system of Kazakhstan. The economic assessment of the implementation of the "Digital Kazakhstan" Program was used to study the subject.

Literature review. A great contribution to the development of the theory and practice of logistics was made by the works of Russian scientists:

Kalinina V. A., Grigorieva A. S.[3], Panova I.V. [4], Dorofeeva A. [5], Astafyeva N.V., Puzanova E.A. [6], Mazlova I.I., Gavrilova S.I. [7]. In the study of issues related with the development of the transport industry of Kazakhstan made such economists as: Mozharova V.V. [8], Erenyazova Zh.N., Talapbaeva G.E., Kultanova N.B. [9], Dnishev F., Alzhanova F. [10], Iztileuova M.S.[13], Satova R.K., Suhova L.K., Guseva L.U.[14], Kaldibayev. S.U., Bizhanova A.S., Ahmediarova A.T., Kasimova D.T. [15].

Main part. The aim of state program "Digital Kazakhstan" is economic growth, increasing competitiveness and improving the quality of life of the population. To date, the implementation of the program involves following five basic principles (figure 1).

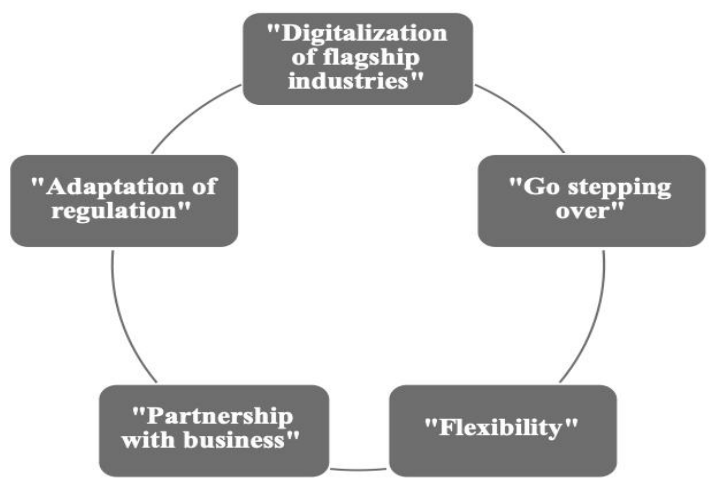

Figure 1. Basic principles*

*Compiled by the author on the basis of source [2]

The first principle, "digitalization of flagship industries" aims to implement the digital transformation of existing industries. The main task of digitalization of industries is a large-scale increase in productivity. This is achieved through the introduction of new technologies and adaptation of existing business processes. As well as creating a favorable ecosystem [3].

The second principle, "go stepping over". Kazakhstan will introduce the most advanced technologies and innovative approaches for longterm development. After all, they are able to ensure the sustainability of the future.

The third principle, "flexibility".When ma- 
king changes to the Program, in cases stipulated by the current system of state planning, the Agile approach can be applied.

The fourth principle, "partnership with business". To achieve greater efficiency, it is important to involve the private sector in the implementation process. In this regard, it is important to create appropriate conditions for large enterprises, as well as small and mediumsized businesses [4].

Attracting investment and reducing costs for the digital transformation of the enterprise is a good support for the massiveness of this process. Especially in specific areas.

The fifth principle, "adaptation of regulation". During the implementation of the program, questions naturally arise. The state should take the initiative in the legislative processes to ensure the conditions of the digitalization process. This should be done on the basis of a comparison of the study of foreign experience. That in turn will help the competitive development of the country [5].

According to the official data Of the Committee on statistics of the Ministry of national economy of the Republic of Kazakhstan (CC MNE RK), in 2018, the transport industry provided Kazakhstan with $8.3 \%$ of the total GDP produced (about 58.8 trillion tenge was the GDP of the Republic by production method). Over the past year, about 4.1 billion tons of goods were transported through the territory of Kazakhstan, which is almost twice as much as a decade ago. In General, the indicator of cargo turnover in the country increased from 369.8 billion tkm to 596.1 billion tkm in the period from 2008 to 2018 , which is $61 \%$ more [6].

The task of digitalization of transport and logistics is also one of the priority directions of digitalization of the economic sector. High-quality transport and logistics infrastructure is the key to economic development of the country. Kazakhstan today has a fairly well-developed railway network, but the road network is not sufficiently developed and air transportation is excessively expensive. A big advantage is the location of the country, its transit potential [7].

The program "Digital Kazakhstan" provides the creation of an intelligent transport system. It will combine the functions of video surveillance, traffic management, driver notification of weather conditions and electronic payment for transport services. The introduction of an intelligent transport system will reduce the number of road accidents, as well as reduce the cost of road maintenance [8]. The use of electronic document management and a system of non-stop weighing of vehicles will ensure smooth transit through the country (figure 2).

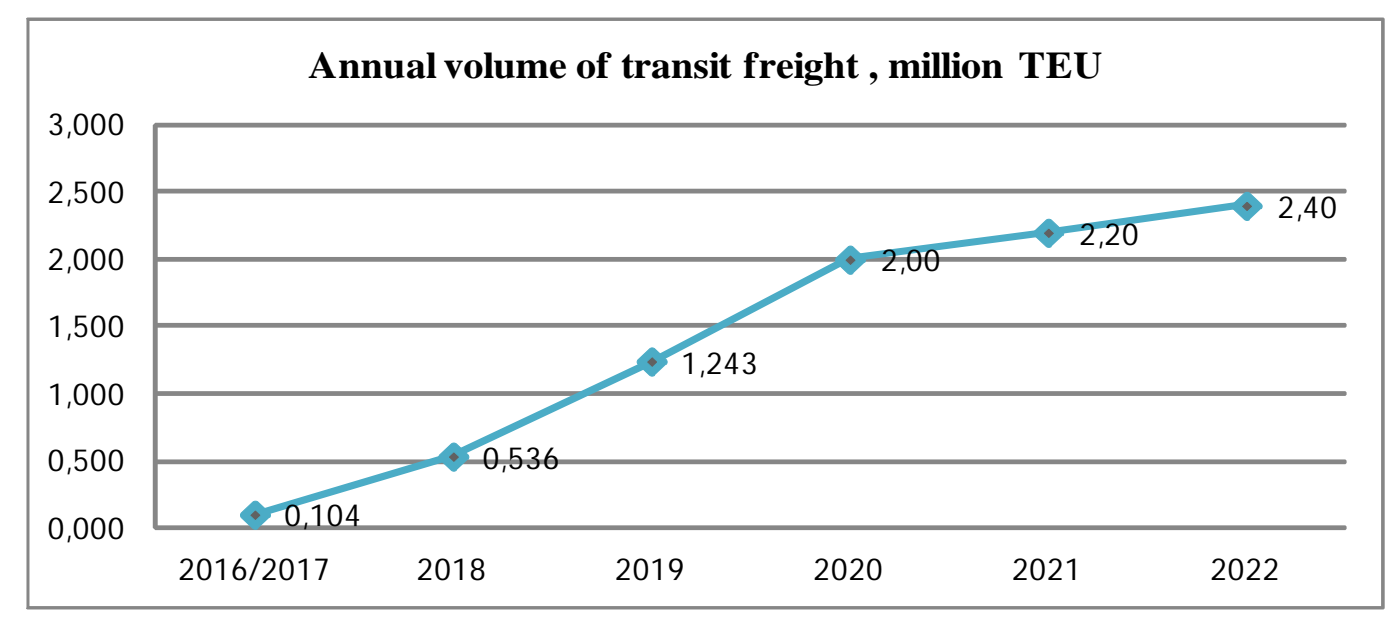

Figure 2. Expected annual volume of transit freight, million TEU*

*Compiled by the author on the basis of source [2] 
In the direction of intelligent transport system. The project "multimodal transport management System" is being implemented in stages, which provides comprehensive automation of transport management processes, management of customer and contractor base, calculations of services and vehicles (figure 3 ).

8 complexes of "Special automated measuring tools" were launched in 2017, fixing the transportation of goods in excess of the established norms. 12 SAIS complexes were launched in 2018, in 2019 it is planned to launch another 26 systems.
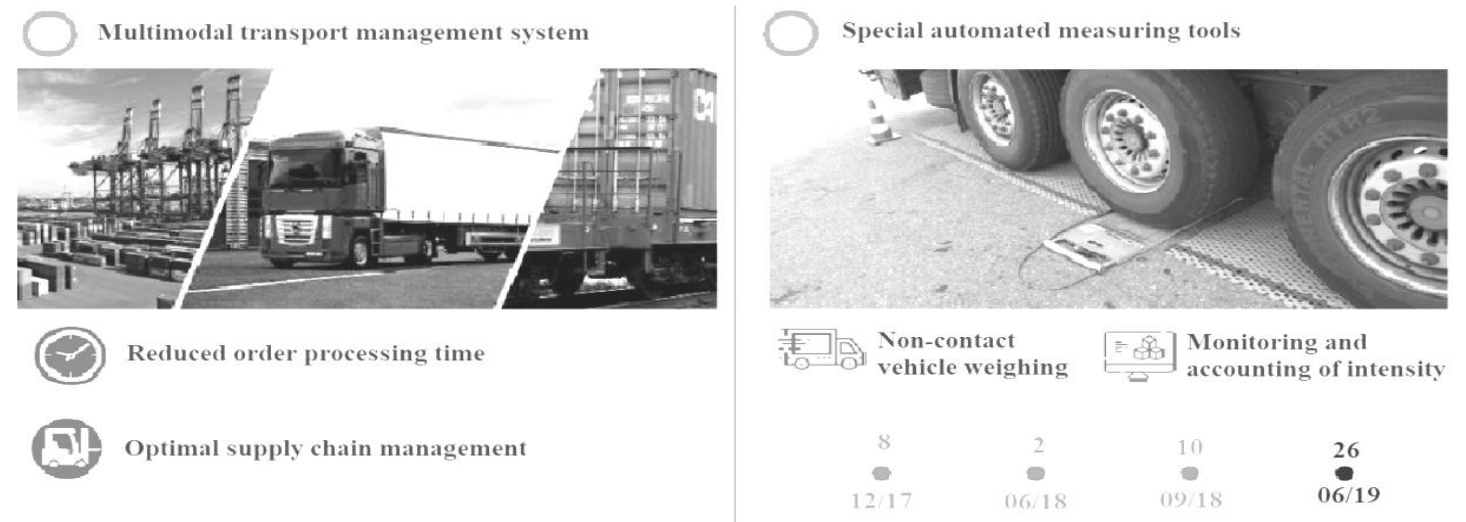

Figure 3. Digitalization of transport and logistics*

*Compiled by the author on the basis of source [15]

A road asset management system is also being implemented, within which 16 mobile laboratories have been launched. The system will provide transparency and quality monitoring of road works, both during repair and during the warranty period [9].

As a result of the implementation of the project "intelligent transport system" in 2018, 279 jobs were created. By 2025, it is planned to create an additional 1.5 thousand jobs [10].

To provide the city of Nur-Sultan with food products, the Ministry of Agriculture has developed a new roadmap for the formation of the food belt of Astana, calculated until 2021. According to which, it is planned to build a meat processing complex, 16 dairy farms and develop trade and logistics infrastructure in the Akmola region.

In 2020-2021, it is planned to build 16 dairy farms to load milk processing enterprises ( 5 in the Akmola region and 11 in the Karaganda region); in 2019-2020, the restoration of irrigated land for growing the missing volumes of vegetables.

The Ministry of Agriculture intends to develop trade and logistics infrastructure simul- taneously. For this purpose, a wholesale distribution center will be created in Nur-Sultan, which will provide an opportunity for domestic agricultural producers to enter the market of wholesale buyers at market "fair" prices, as well as reduce the cost of storing products, increase the turnover of agricultural producers [11].

Within the framework of the preferential financing program of JSC "NC "SEC "Astana”, loans were issued to Kenmart and Astykzhan shopping centers in the amount of 300 million tenge to replenish working capital in exchange for price fixing in Astana last year. As a result, fixed prices were set for 49 products. As part of the implementation of food belt projects around Astana within a radius of $50 \mathrm{~km}, 92$ projects (16 - dairy, 56 - meat and 20 - other projects) have been identified [12].

In terms of food security, digitalization will modernize the country's trade infrastructure. To form a coherent and effective trade and logistics infrastructure, a national commodity distribution system is being created. This will allow to unite transport agents, intermediaries and retailers into 


\section{Менеджмент және маркетинг / Менеджммен и маркетинг}

a single cluster, both technically and informationally. 24 wholesale distribution centers will provide connecting into a single digital system and optimizing the supply chain of products from manufacturer to consumer, creating the necessary conditions for storage, effective distribution and sale of products. Reducing commodity losses will ensure farmers with the opportunity to invest further in increased productivity. In addition, full direct access of a private manufacturer to sales markets and pre-sale trade infrastructure will significantly increase the income of both the private trader and the industry as a whole. At the same time, the consumer will receive quality, safe products and improved service. Moreover, the prices for socially important food products will be reduced by $45 \%$. This will save about 60 billion tenge for consumers annually [13].

Creation of conditions for ensuring stable supplies of food products from other regions of the Republic, the production of which is impractical in the zone of the food belt. For this purpose, the mechanism for assigning the status of "Participant of the food belt of the capital" will be introduced, which will provide the subjects of the agroindustrial complex with priority access to markets in the city, including municipal markets, etc.[14].

Development of trade and logistics infrastructure. For this purpose, a wholesale distribution center will be created in Astana to provide an opportunity for domestic agricultural producers to enter the market of wholesale buyers [15].
Implementation of additional measures to protect the market from nonconforming products. This is the strengthening of interaction of state bodies to protect the market from inappropriate products by increasing the volume of research, monitoring the safety of imported and manufactured products with media coverage of the facts of violations of the legislation requirements of the Republic of Kazakhstan.

Conclusion. In comparison with Western countries, Japan and the United States the development of IT technologies in many sectors of Kazakhstan's economy was not efficient. Obviously it is important to carry out digital modernization in industries as soon as possible. Since the competitiveness of the economy of Kazakhstan and, accordingly, the welfare of citizens directly depends on it. According to the state program "Digital Kazakhstan", the growth of labor productivity in the section" Transport and warehousing "in 2022 should be about $21 \%$.

As you know, logistics costs of domestic producers in the structure of the cost of finished products in the equity ratio is about $40 \%$. Therefore, it will be possible to reduce logistics costs several times due to the construction of infrastructure and the choice of optimal routes for the transportation of goods by manufacturers.

As a result, a number of larger problems arise. The level of automation in industrial production and the use of new technologies remains low. Lack of professional staff with sufficient competence.

\section{REFERENCES}

1. Strategija «Kazahstan-2050»: novyj politicheskij kurs sostojavshegosja gosudarstva. Poslanie Prezidenta Respubliki Kazahstan - Lidera Nacii N.A. Nazarbaeva narodu Kazahstana. - Astana, 14 dekabrja 2012 goda. http://adilet.zan.kz/rus/docs/K1200002050/links [in Russian].

2. Gosudarstvennaja programma «Cifrovoj Kazahstan». Postanovlenie Pravitel'stva Respubliki Kazahstan ot 12 dekabrja 2017 goda № 827. https://www.akorda.kz/upload/media/files/ a0632264810b20c36ed2a4f55d095ad2.docx [in Russian].

3. Kalinin V.A., Grigor'eva A.S. Innovacii v transportnoj otrasli: jeffekt ot vnedrenija tehnologii SAW RFID // Nauka i transport. Modernizacija zheleznodorozhnogo transporta. - 2013. - № 2(6). - S. 20-21 [in Russian].

4. Panova I.V. Upravlenie operacionnoj logisticheskoj dejatel'nost'ju pri vzaimodejstvii zheleznodorozhnogo i vodnogo transporta. Avtoreferat dissertacii na soiskanie uchenoj stepeni kandidata 
jekonomicheskih nauk. - Saratov, 2012. - 16 s.

5. Dorofeev A. Trendy razvitija transportnoj logistiki // Logistika. - 2011 . - №2. - S. 21-23 [in Russian].

6. Astaf'eva N.V., Puzanova E.A. Vybor kanala raspredelenija gotovoj produkcii kak vazhnejshij aspekt raspredelitel'noj logistiki. Logistika, innovacii, menedzhment v sovremennoj biznes-srede // Sbornik nauchnyh trudov. - Tom 2. - Saratov, 2010. - S. 6-10 [in Russian].

7. Mazlov I.I., Gavrilov S.I. Sovremennye problemy transportnoj logistiki v Rossii i puti ih reshenija // Mezhdunarodnyj nauchno-tehnicheskij zhurnal «Teorija. Praktika. Innovacii», aprel' 2018.

8. Mozharova V.V. Transport v Kazahstane: sovremennaja situacija, problemy i perspektivy razvitija: Monografija. - Almaty: KISI pri Prezidente RK, 2011. - 216 s. [in Russian].

9. Ernijazova Zh.N., Talapbaeva G.E., Kultanova N.B. Predposylki formirovanija klastera transportnoj logistiki v Respublike Kazahstan // Mezhdunarodnyj zhurnal prikladnyh i fundamental'nyh issledovanij. - 2014. - № 5-1. - S. 132-135 [in Russian].

10. Razvitie innovacij i progressivnyh tehnologicheskih ukladov v jekonomike Kazahstana v uslovijah industrial'noj modernizacii: instituty, mehanizmy i prioritety: Monografija / Pod red. F. Dnishev, F. Al'zhanova. - Vena, Avstrija: Associacija perspektivnyh issledovanij i vysshego obrazovanija «Vostok-Zapad», 2015. - 532 s. [in Russian].

11. Dorozhnaya karta po formirovaniyu prodovol'stvennogo poyasa goroda Astany' na 2018 2021 gody ' (s izmeneniyami ot 12.11.2018 g.). Postanovlenie Pravitel'stva Respubliki Kazakhstan ot 13 oktyabrya 2017 goda № 645 [in Russian].

12. Prodovol'stvennyj pojas Astany: Rezul'taty, plany i poruchenija. Kapital. [Jelektronnyj resurs]. - Rezhim dostupa://https://kapital.kz/economic/73480/prodovol-stvennyy-poyas-astany-rezul-tatyplany-i-porucheniya.html [in Russian].

13. Oficial'nyj informacionnyj resurs Prem'er-Ministra Respubliki Kazahstan. Regional'naja integracija, podderzhka jeksporta, vnedrenie cifrovizacii-kak razvivaetsja torgovaja otrasl' Kazahstana. 20 avgusta 2020. https://primeminister.kz/ru/news/reviews/regionalnaya-integraciya-podderzhkaeksporta-vnedrenie-cifrovizacii-kak-razvivaetsya-torgovaya-otrasl-kazahstana-2073830 [in Russian].

14. Satova R.K., Suhova L.K., Guseva L.Ju. Transport - strategicheskij resurs obespechenija bezopasnosti i povyshenija konkurentosposobnosti Kazahstana // Mezhd. nauch.-prakt. konf. «Transport Evrazii XXI veka». - Almaty, 2006. - 17-21 s. [in Russian].

15. Kaldybaev S.U., Bizhanova A.S., Ahmedijarova A.T., Kasymova D.T. Avtomattandyrylғan basқaru zhyjeleri: Оқиlуқ. - Almaty: DYuir, 2011. - 232 b. [in Kazakh].

\section{ЛИТЕРАТУРА}

1. Стратегия «Казахстан-2050»: новый политический курс состоявшегося государства Послание Президента Республики Казахстан - Лидера Нации Н.А. Назарбаева народу Казахстана. - Астана, 14 декабря 2012 года. http://adilet.zan.kz/rus/docs/K1200002050/links

2. Государственная программа «Цифровой Казахстан». Постановление Правительства Республики Казахстан от 12 декабря 2017 года № 827. https://www.akorda.kz/upload/media/ files/a0632264810b20c36ed2a4f55d095ad2.docx

3. Калинин В.А., Григорьева А.С. Инновации в транспортной отрасли: эффект от внедрения технологии SAW RFID // Наука и транспорт. - 2013. - № 2(6). - С. 20-21.

4. Панова И.В. Управление операционной логистической деятельностью при взаимодействии железнодорожного и водного транспорта: Автореф. дисс. на соиск. уч. степ. к.э.н. - Саратов, 2012. - 16 с. 


\section{Менеджмент жсәне маркетинг / Менеджмент и маркетинг}

5. Дорофеев А. Тренды развития транспортной логистики // Логистика. - 2011. № 2. - С. 21-23.

6. Астафьева Н.В., Пузанова Е.А. Выбор канала распределения готовой продукции как важнейший аспект распределительной логистики. Логистика, инновации, менеджмент в современной бизнес-среде // Сборник научных трудов. - Т. 2. - Саратов, 2010. - С. 6-10.

7. Мазлов И.И., Гаврилов С.И. Современные проблемы транспортной логистики в России и пути их решения // Междунар. науч.-технич. журнал «Теория. Практика. Инновации», апрель 2018.

8. Можарова В.В. Транспорт в Казахстане: современная ситуация, проблемы и перспективы развития. - Алматы: КИСИ при Президенте РК, 2011. - 216 с.

9. Ерниязова Ж.Н., Талапбаева Г.Е., Култанова Н.Б. Предпосылки формирования кластера транспортной логистики в Республике Казахстан // Международный журнал прикладных и фундаментальных исследований. - 2014. - № 5-1. - С. 132-135.

10. Развитие инноваций и прогрессивных технологических укладов в экономике Казахстана в условиях индустриальной модернизации: институты, механизмы и приоритеты: Монография / Под ред. Ф. Днишев, Ф. Альжанова. - Вена, Австрия: Ассоциация перспективных исследований и высшего образования «Восток-Запад», 2015. - 532 с.

11. Дорожная карта по формированию продовольственного пояса города Астаны на 2018-2021 годы (с изм. от 12.11.2018 г.). Постановление Правительства Республики Казахстан от 13 октября 2017 года № 645.

12. Продовольственный пояс Астаны: Результаты, планы и поручения. Капитал. [Электронный ресурс]. - Режим доступа: //https://kapital.kz/economic/73480/prodovol-stvennyypoyas-astany-rezul-taty-plany-i-porucheniya.html

13. Официальный информационный ресурс Премьер-Министра Республики Казахстан. Региональная интеграция, поддержка экспорта, внедрение цифровизации - как развивается торговая отрасль Казахстана. 20 августа 2020. https://primeminister.kz/ru/news/reviews/ regionalnaya-integraciya-podderzhka-eksporta-vnedrenie-cifrovizacii-kak-razvivaetsya-torgovayaotrasl-kazahstana-2073830

14. Сатова Р.К., Сухова Л.К., Гусева Л.Ю. Транспорт - стратегический ресурс обеспечения безопасности и повышения конкурентоспособности Казахстана // Межд. науч.практ. конф. «Транспорт Евразии XXI века». - Алматы, 2006. - 17-21 с.

15. Қалдыбаев С.У., Бижанова А.С., Ахмедиярова А.Т., Қасымова Д.Т. Автоматтандырылған басқару жүйелері: Оқулық. - Алматы: Дәуір, 2011. - 232 б.

\section{Б.К. Жуманова, Н.М. Алашбаева, А.Б. Имашев, К.К. Байгабулова \\ ҚАЗАҚСТАННЫҢ КӨЛІКТІК-ЛОГИСТИКАЛЫҚ ЖУЙЕСІН БАСҚАРУДА ЦИФРЛЫҚ ТЕХНОЛОГИЯНЫ ЕНГІЗУ}

\section{Андатпа}

Мақалада Қазақстан экономикасының көлік-логистикалық секторын цифрландыру мәдениетін қалыптастыру шарттары қарастырылған және жаңа технологияларды енгізу мен қолданыстағы бизнес-процестерді жетілдіру арқылы экономикалық салаларды дамытудың негізгі принциптеріне негізделген «Цифрлық Қазақстан» мемлекеттік бағдарламасын іске асырудың негізгі кезеңдері қарастырылған. Авторлар көлік-логистикалық құрылымын дамытудың мақсаттары мен міндеттерін анықтады. Интеллектуалды көлік жүйесі жобасының бірізділігі көрсетілген. 
Қазақстан Республикасы экономикасының заманауи дамуы шеңберінде көлік саласын зерттеу нәтижелері бойынша мақала авторлары логистикалық қызметтердің жоғары шығындарымен және еңбек өнімділігінің төмендігімен байланысты одан әрі дамудың негізгі проблемалық аспектілері мен шектеулерін анықтады. Зерттеу нәтижелері бойынша Қазақстан экономикасының секторларында көлік-логистикалық қызметтерді цифрлық модернизациялау қажеттілігі негізделді.

\title{
Б.К. Жуманова, Н.М. Алашбаева, А.Б. Имашев, К.К. Байгабулова \\ ВНЕДРЕНИЕ ЦИФРОВИЗАЦИИ В УПРАВЛЕНИЕ ТРАНСПОРТНО- ЛОГИСТИЧЕСКОЙ СИСТЕМОЙ КАЗАХСТАНА
}

\begin{abstract}
Аннотация
В представленной статье приведены условия формирования культуры цифровизации транспортно-логистической сферы экономики Казахстана и рассмотрены основные этапы реализации государственной программы «Цифровой Казахстан», на основе основных принципов развития отраслей экономики, за счет внедрения новых технологий и совершенствования действующих бизнес-процессов. Авторами определены цели и задачи развития транспортно-логистической структуры. Показана согласованность функционирования проекта интеллектуальной транспортной системы.

По результатам исследования транспортной отрасли в рамках современного развития экономики Республики Казахстан авторы статьи выделили основные проблемные стороны и сдерживающие факторы дальнейшего развития, связанные с высокими затратами логистических услуг и низкой производительностью труда. По итогам проведенного исследования обоснована необходимость цифровой модернизации транспортно-логистических услуг в отраслях экономики Казахстана.
\end{abstract}

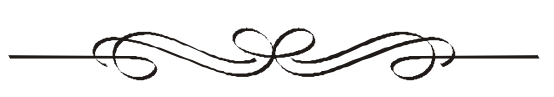

